\title{
Polar Lipids in Methanogen Taxonomy
}

\author{
By W. D. GRANT, ${ }^{*}$ G. PINCH, ${ }^{1}$ J. E. HARRIS, ${ }^{2}$ M. DE ROSA ${ }^{3}$ AND \\ A. GAMBACORTA ${ }^{3}$ \\ ${ }^{1}$ Department of Microbiology, University of Leicester, Leicester LE1 7RH, UK \\ 2 AFRC Food Research Institute, Colney Lane, Norwich NR4 7UA, UK \\ ${ }^{3}$ Istituto per la Chimica di Molecole di Interesse Biologico, Arco Felice, \\ Via Toiano 6, Napoli, Italy
}

(Received 27 June 1985 ; revised 9 August 1985)

\begin{abstract}
Polar lipid patterns of representative methanogens were recorded by two-dimensional thin-layer chromatography. Phenotypically similar Methanobacterium spp., Methanobrevibacter spp. and Methanomicrobium spp. could readily be distinguished from each other. Similarly, Methanogenium spp. and phenotypically similar Methanococcus spp. had different polar lipid patterns. Single examples from the monospecific genera Methanospirillum, Methanoplanus and Methanothermus had distinctive polar lipid patterns, but Methanolobus tindarius had a similar pattern to Methanosarcina spp. The isopranoid ether lipid cores from the polar lipids were identical for those species within any one genus. Novel core lipids were identified in examples from the genera Methanomicrobium, Methanosarcina and Methanolobus.
\end{abstract}

\section{INTRODUCTION}

The methane-producing archaebacteria comprise a physiologically similar but genotypically diverse group of prokaryotes (Archer \& Harris, 1985; Balch et al., 1979). Taxonomic relationships are primarily determined by comparative cataloguing of $16 \mathrm{~S}$ rRNA (Balch et al., 1979). The 16S rRNA groups are consistent with those groups derived by nucleic acid hybridization (Tu et al., 1982), the immunological comparison of ribosomal proteins (Schmid \& Bock, 1981) and total sequence comparisons of 5S rRNA (Fox et al., 1982). All of these techniques are technically demanding and unsuitable for the rapid identification of new isolates. Complex immunological procedures for the identification of new isolates are available (Macario \& Conway de Macario, 1983), but these methods rely on the availability of a bank of appropriate antisera and it is reported that only two isolates per week may be processed.

Phenotypic characters are often of limited use in the identification of new isolates in view of the relative uniformity of substrate utilization in methanogenesis (Archer \& Harris, 1985). The morphology of the cell may be of considerable use where an isolate has a distinct and characteristic cell shape and cell wall (e.g. Methanosarcina or Methanospirillum spp.) but often isolates are rather pleomorphic and difficult to assign readily to any group. In this respect we have found the genera Methanococcus and Methanogenium particularly difficult to distinguish. Similarly, rod-shaped cells are often difficult to assign to the genera Methanobacterium, Methanobrevibacter or Methanomicrobium because of variation in cell length and filamentation dependent on growth conditions.

Chemotaxonomic procedures such as cell wall analyses have not been widely used in the identification of methanogens. Cell wall composition (pseudomurein, protein, heteropolysaccharide) can be used to assign an isolate to family and in some cases genus level (Balch et al., 1979), but a more detailed analysis of each cell wall type would be required for this approach to be of general use at genus and species level. Polyamine distribution is consistent with family relationships derived from $16 \mathrm{~S}$ rRNA cataloguing (Scherer \& Kneifel, 1983), but of little use in distinguishing genera and species. 
The analysis of polar lipid composition by two-dimensional thin-layer chromatography (TLC) has proved to be a rapid and simple technique for classifying halophilic archaebacteria, polar lipid groups being consistent with groups derived by $16 \mathrm{~S}$ rRNA/DNA hybridizations (Ross \& Grant, 1985). Preliminary results have also indicated that the technique is of use in the identification of different methanogen genera, and might have considerable potential for species differentiation in view of the extremely complex lipid patterns observed (Ross et al., 1985). The lipophilic core components of the polar lipids of archaebacteria are saturated isopranoid ethers, typical types being diphytanylglycerol diether (abbreviated as $\mathrm{C}_{20} \mathrm{C}_{20}$; Fig. $1 a$ ), 2-O-sesterterpanyl-3-O-phytanylglycerol diether (abbreviated as $\mathrm{C}_{20} \mathrm{C}_{25}$; Fig. 1 b) and bidiphytanyldiglycerol tetraether (abbreviated as $\mathrm{C}_{40} \mathrm{C}_{40}$; Fig. $1 c$ c). $\mathrm{C}_{40} \mathrm{C}_{40}$ core components may be partly cyclized (Langworthy et al., 1982; De Rosa et al., 1982). In the present study, thinlayer chromatograms of polar lipids and their isopranoid ether lipid cores have been determined for a comprehensive range of methanogens.

\section{METHODS}

Strains and culture conditions. Details of strains, substrates and growth conditions are shown in Table 1. Cultures $(400 \mathrm{ml})$ were grown in 1 litre bottles on either methanol $(1 \%, \mathrm{v} / \mathrm{v})$ or $\mathrm{H}_{2} / \mathrm{CO}_{2}(4: 1, \mathrm{v} / \mathrm{v})$ as substrate as described previously (Ross et al., 1985). Cells were harvested at the stationary phase and freeze-dried.

Lipid analyses. Polar lipids were extracted by the procedure of Bligh \& Dyer (1959) as modified by Minnikin et al. (1979) and analysed by two-dimensional TLC (Ross et al., 1985). To determine the type of lipids present on the chromatograms a variety of differential stains were used. Total lipids were detected by charring with ethanolic deca-molybdophosphoric acid (Ross et al., 1981), phospholipids were identified by the Zinzadze reagent of Dittmer \& Lester (1964), glycolipids were revealed with the $\alpha$-naphthol-sulphuric acid reagent of Jacin \& Mishkin (1965) and aminolipids were shown by spraying with $0 \cdot 2 \%(\mathrm{w} / \mathrm{v})$ ninhydrin in water-saturated butanol followed by heating at $105^{\circ} \mathrm{C}$ for $10 \mathrm{~min}$.

Diether and tetraether core lipids were extracted after acid methanolysis (Ross et al., 1981) and analysed by TLC (Ross et al., 1981, 1985).

\section{RESULTS AND DISCUSSION}

\section{Analysis of polar lipids}

Polar lipid patterns derived from single examples from each of four genera are shown in Fig. 2. Methanothermus, Methanospirillum and Methanoplanus are presently monospecific genera and we have examined only one of the two Methanomicrobium spp.; it is not possible therefore to be certain that an overall generic pattern exists for each of these genera. However, the four isolates were distinguished both in terms of the overall patterns and the presence or absence of particular classes of lipid. Kushwaha et al. (1981) have analysed the main lipids of Methanospirillum hungatii and we have speculated on the identity of the major spots shown here (Fig. $2 a$ ) for this isolate (Ross et al., 1985); to date this is the only methanogen to be examined in detail.

The polar lipid patterns shown in Fig. 2 are also clearly distinguishable from those of a representative number (at least half the named species) of members of six other genera, Methanobacterium, Methanobrevibacter, Methanococcus, Methanogenium, Methanosarcina and Methanolobus (Figs 3-5). Overall generic markers can be defined from comparisons of several species of each of these genera. Three Methanobacterium spp. are compared with three Methanobrevibacter spp. in Fig. 3. Methanobrevibacter spp. are characterized by three aminophospholipids not present in Methanobacterium spp., whereas Methanobacterium spp. have characteristic aminoglycophospholipids and two aminophospholipids not present in Methanobrevibacter spp. Despite sharing a common generic pattern, the patterns obtained for different species are sufficiently different from each other to allow positive identification.

Methanogenium spp. are compared with Methanococcus spp. in Fig. 4. The Methanococcus patterns are all rather similar and very characteristic. Marker features for the genus include the presence of two major glycolipids and a group of two or three phospholipids in the upper centre of the chromatogram. Methanogenium spp. have quite different patterns, being considerably more complex. Although Methanogenium thermophilicum and Methanogenium marisnigri have some similarities, Methanogenium cariaci appears quite different and it is difficult to define any clear generic markers. $16 \mathrm{~S}$ rRNA cataloguing studies indicate that these Methanogenium spp. 
(a)<smiles>CC(C)CCCC(C)CCCC(C)CCCC(C)CCOC(CO)COCCC1CCCC(C)CCCC(CCCC(C)C)CC1</smiles>

(b)<smiles>CC(C)CCCC(C)CCCC(C)CCCC(C)CCCC(CCCC(C)CCCC(C)CCCC(C)C)CCCC(C)CCOCC(C)CO</smiles>

(c)

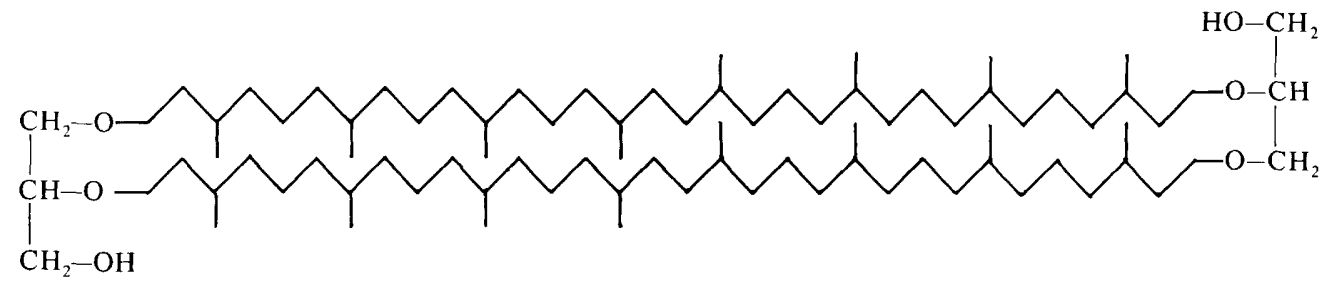

Fig. 1. Core glycerol ether lipids of archaebacteria: $(a)$ diphytanylglycerol diether $\left(\mathrm{C}_{20} \mathrm{C}_{20}\right) ;($ b) $2-O$ sesterterpanyl-3-O-phytanylglycerol diether $\left(\mathrm{C}_{20} \mathrm{C}_{25}\right) ;(c)$ bidiphytanyldiglycerol tetraether $\left(\mathrm{C}_{40} \mathrm{C}_{40}\right)$.

Table 1. Strains and growth conditions

Species

Methanobacterium bryantii

Methanobacterium formicicum

Methanobacterium thermoautotrophicum

Methanobrevibacter smithii

Methanobrevibacter ruminantium

Methanobrevibacter arboriphilicus

Methanothermus fervidus

Methanococcus vannielii

Methanococcus voltae

Methanococcus thermolithotrophicus

Methanomicrobium mobile

Methanogenium cariaci

Methanogenium marisnigri

Methanogenium thermophilicum

Methanospirillum hungatii

Methanoplanus limicola

Methanosarcina barkeri

Methanosarcina mazei

Methanolobus tindarius
Strain

no.

DSM 862

DSM 1535

DSM 1053

DSM 861

DSM 1093

DSM 744

DSM 2088

DSM 1224

DSM 1537

DSM 2095

DSM 1539

DSM 1497

DSM 1498

DSM 2373

DSM 864

DSM 2279

DSM 800

DSM 2053

DSM 2278

Growth
temp. $\left({ }^{\circ} \mathrm{C}\right)$

37

37

65

37

37

25

85

37

37

65

37

25

25

55

37

37

37

37

25
Basic medium* Substrate

$\begin{array}{cl}\mathrm{M} 1 & \mathrm{H}_{2} / \mathrm{CO}_{2} \\ \mathrm{M} 1 & \mathrm{H}_{2} / \mathrm{CO}_{2} \\ \mathrm{M} 1 & \mathrm{H}_{2} / \mathrm{CO}_{2} \\ \mathrm{M} 1 & \mathrm{H}_{2} / \mathrm{CO}_{2} \\ \mathrm{M} 1 \dagger & \mathrm{H}_{2} / \mathrm{CO}_{2} \\ \text { M1 } & \mathrm{H}_{2} / \mathrm{CO}_{2} \\ \text { M1 } & \mathrm{H}_{2} / \mathrm{CO}_{2} \\ \text { M3 } & \mathrm{H}_{2} / \mathrm{CO}_{2} \\ \text { M3 } & \mathrm{H}_{2} / \mathrm{CO}_{2} \\ \text { M3 } & \mathrm{H}_{2} / \mathrm{CO}_{2} \\ \text { MMO } & \mathrm{H}_{2} / \mathrm{CO}_{2} \\ \text { M3 } & \mathrm{H}_{2} / \mathrm{CO}_{2} \\ \text { M3 } & \mathrm{H}_{2} / \mathrm{CO}_{2} \\ \text { M3 } & \mathrm{H}_{2} / \mathrm{CO}_{2} \\ \text { M1 } & \mathrm{H}_{2} / \mathrm{CO}_{2} \\ \text { M3 } & \mathrm{H}_{2} / \mathrm{CO}_{2} \\ \text { M1 } & \mathrm{CH}_{3} \mathrm{OH} \\ \text { M1 } & \mathrm{CH}_{3} \mathrm{OH} \\ \text { M3 } & \mathrm{CH}_{3} \mathrm{OH}^{2}\end{array}$

DSM, Deutsche Sammlung von Mikroorganismen, Munich, FRG

* M3 is medium 3 of Balch et al. (1979) for marine isolates, supplemented with $\mathrm{NiCl}\left(0 \cdot 01 \mathrm{~g} \mathrm{l}^{-1}\right)$ and $\mathrm{Na}_{2} \mathrm{SeO}_{3}$ $\left(0.01 \mathrm{~g}^{-1}\right)$. M1 is the low salt modification of M3 as described by Ross et al. (1985). MMO is as M3 except that Casamino acids $\left(0.6 \mathrm{~g}^{-1}\right)$, tryptone $\left(0.6 \mathrm{~g}^{-1}\right)$, vitamin solution $\left(10 \mathrm{ml} \mathrm{l}^{-1}\right)$ (Balch et al., 1979), clarified rumen fluid $(30 \%, \mathrm{v} / \mathrm{v})$ and $2 \%(\mathrm{v} / \mathrm{v})$ fatty acid solution are added before autoclaving. Composition of fatty acid solution $\left(\mathrm{g} \mathrm{l}^{-1}\right)$ : valeric acid, 0.5 ; isovaleric acid, 0.5 ; methylbutyric acid, 0.5 ; isobutyric acid, 0.5 .

$\dagger$ Coenzyme $\mathrm{M}$ (2-mercaptoethanesulphonate) added at $0 \cdot 1 \mathrm{~g} \mathrm{ml}^{-1}$. 


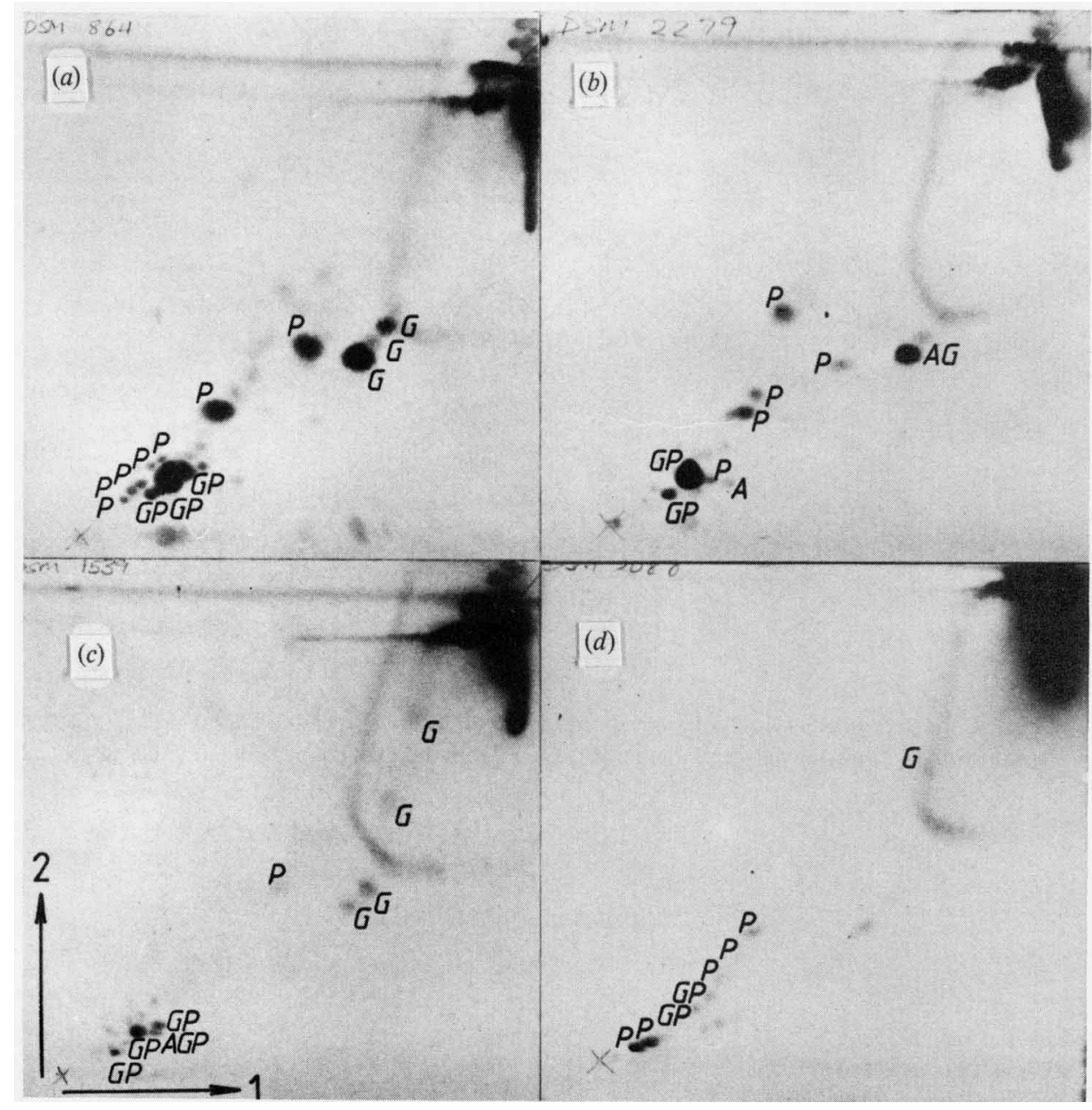

Fig. 2. Polar lipid patterns of species from different methanogen genera: (a) Methanospirillum hungatii; (b) Methanoplanus limicola; (c) Methanomicrobium mobile; (d) Methanothermus fervidus. Chloroform/ methanol/water $(65: 25: 4$, by vol.) was used in the first dimension followed by chloroform/methanol/ acetic acid/water $(80: 12: 15: 4$, by vol.) in the second dimension. Abbreviations: A, aminolipid; G, glycolipid; P, phospholipid.

are as closely related to each other as the Methanococcus spp. (Balch et al., 1979; Jones et al., 1983), so the lack of a clear generic polar lipid pattern here is unexpected.

Polar lipid patterns of Methanosarcina spp. and Methanolobus tindarius are shown in Fig. 5. These patterns are extremely similar and characterized by the total lack of glycolipids. Although both genera are methylotrophic (Table 1), Methanolobus tindarius does not possess the heteropolysaccharide cell wall characteristic of Methanosarcina spp. Methanolobus tindarius awaits 16S RNA oligonucleotide analysis, but rRNA and DNA homology studies suggest that it should be assigned to the family Methanosarcinaceae (Sowers et al., 1984).

No attempt has been made to identify the polar lipid components in Figs 2-5, characterization being limited to their response to the various TLC spray reagents. There are certain apparent discrepancies between some of the patterns shown here and those shown in the preliminary study of Ross et al. (1985). An incomplete range of spray reagents was used in the earlier study, hence a number of spots previously identified as glycolipids are shown here to be glycophospholipids. Additionally, an aminophospholipid in Methanosarcina barkeri and a 


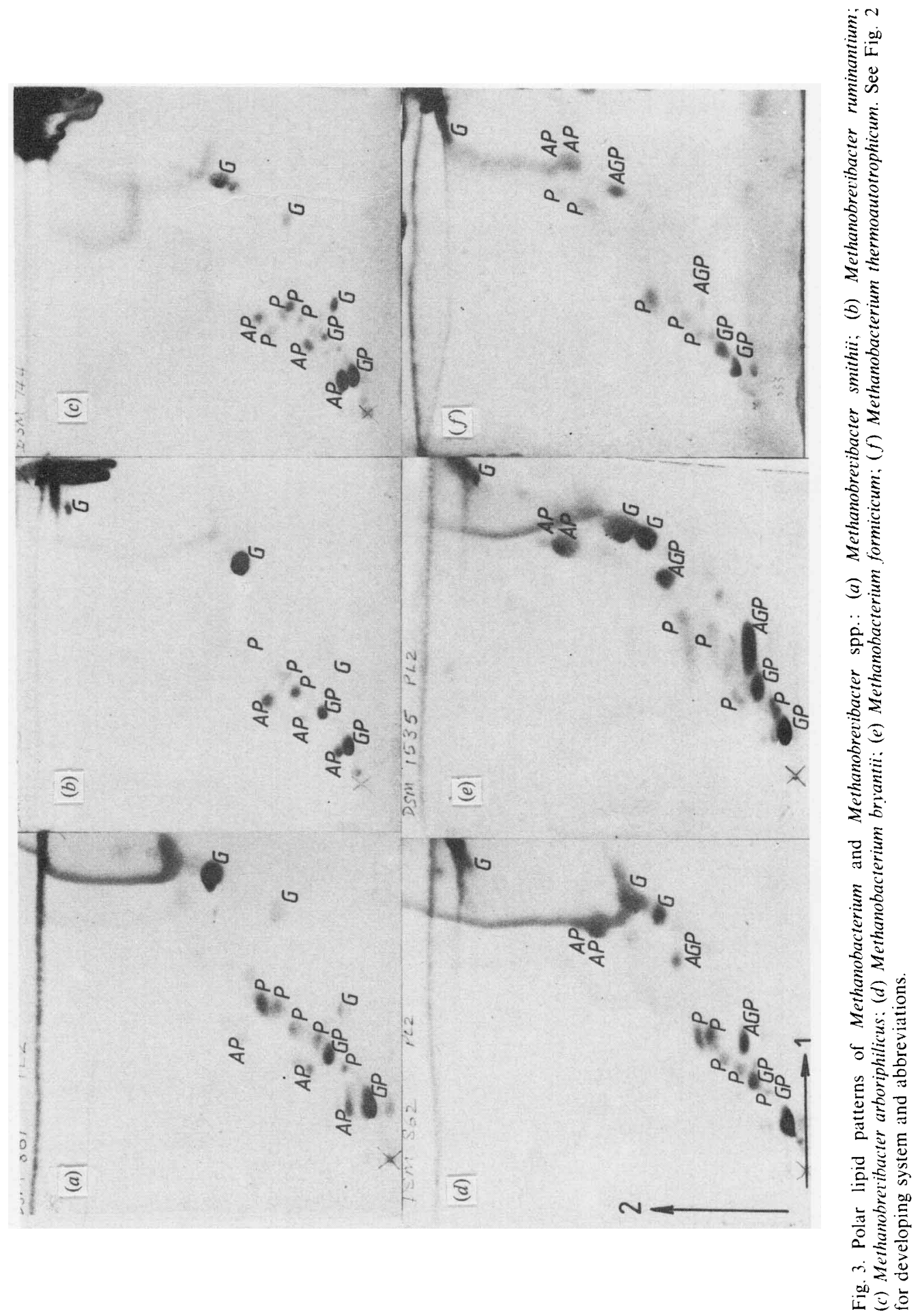




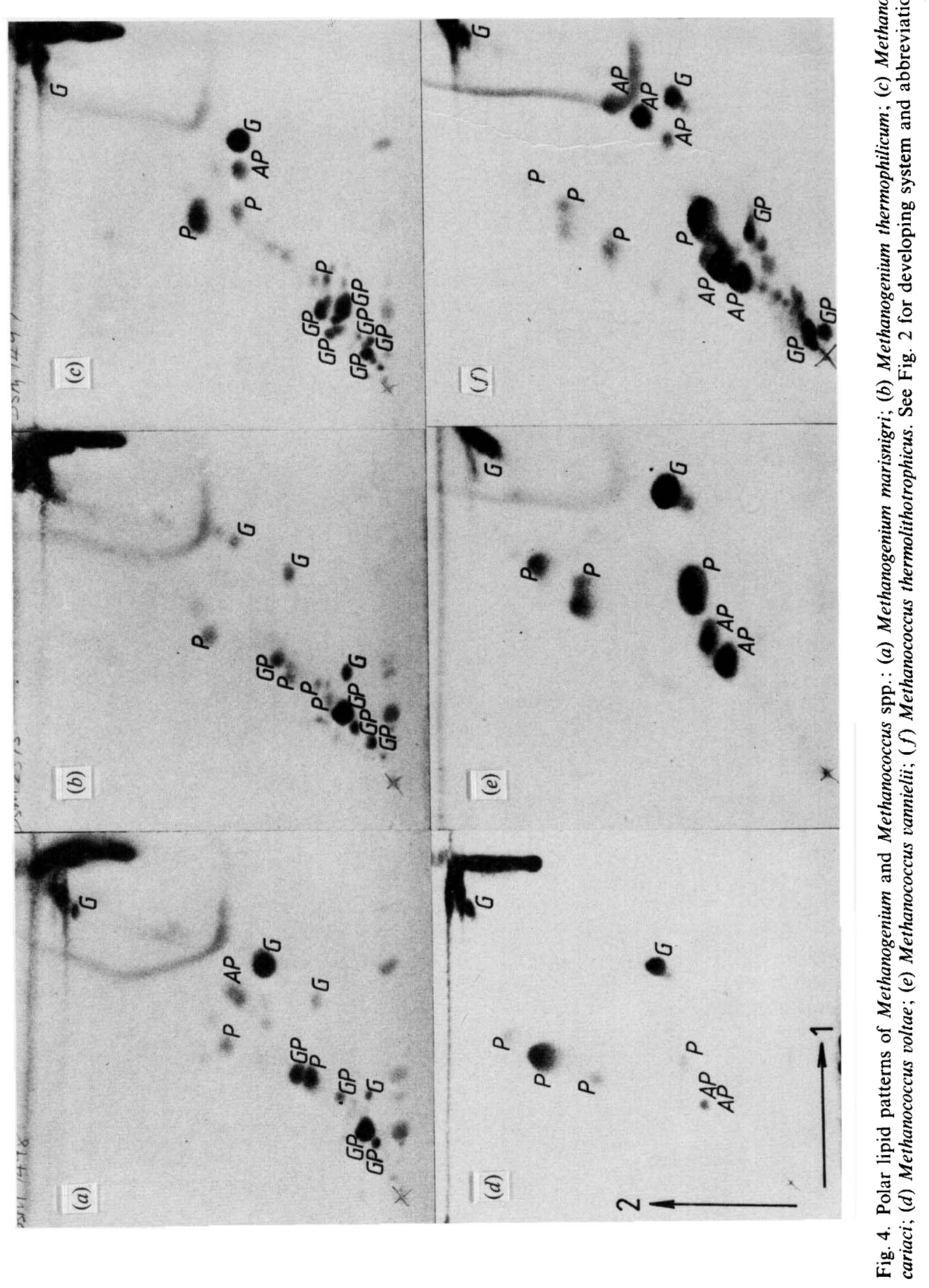




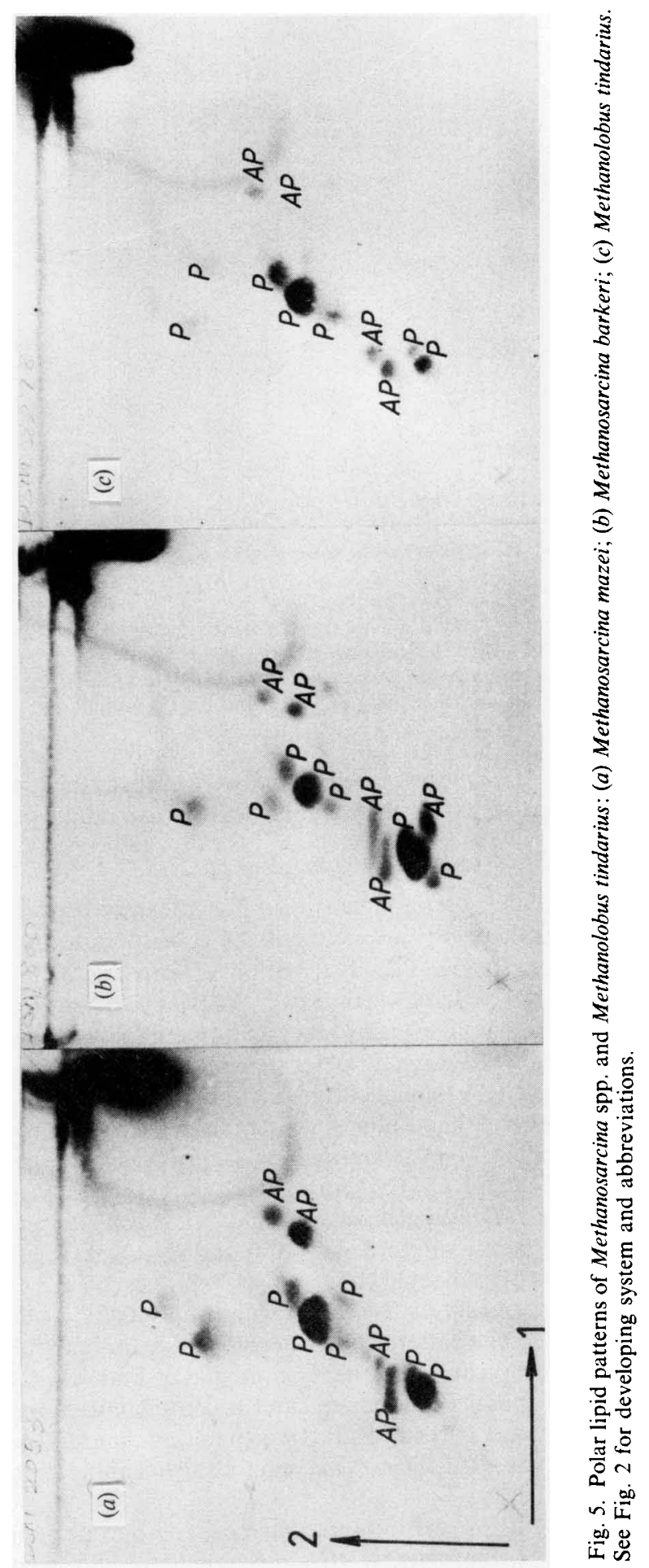




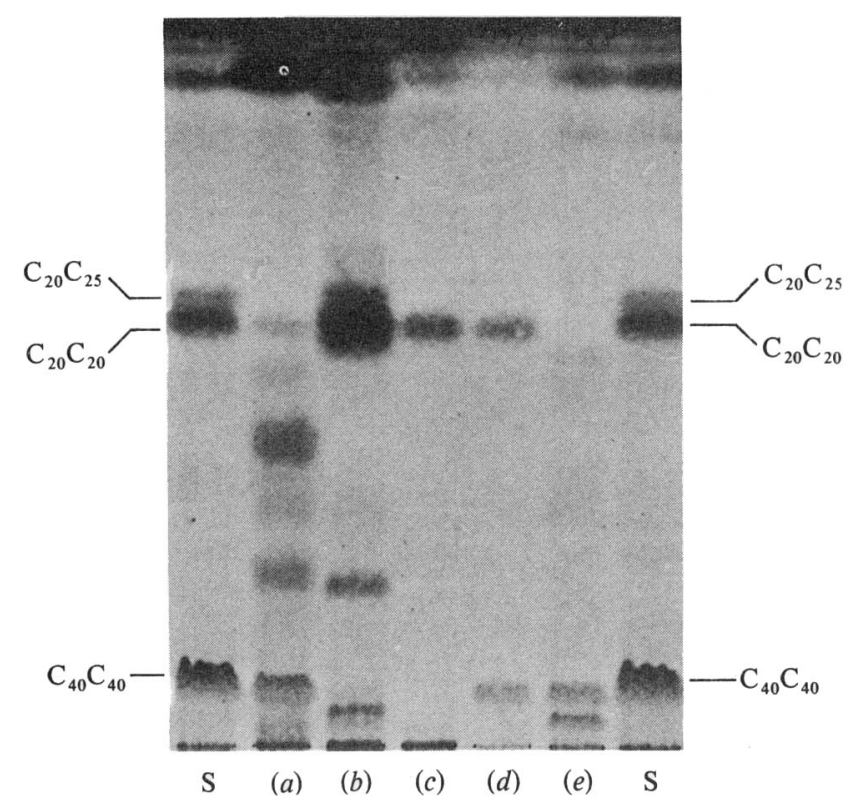

Fig. 6. TLC of core ether lipids using a double development system with light petroleum (b.p. $60-$ $\left.80^{\circ} \mathrm{C}\right)$ /acetone $(95: 5, \mathrm{v} / \mathrm{v})$ followed by toluene/acetone $(97: 3, \mathrm{v} / \mathrm{v})$ in the same dimension. $(a)$ Methanomicrobium mobile; (b) Methanosarcina barkeri; (c) Methanococcus vannielii; (d) Methanogenium cariaci; (e) Methanothermus fervidus; $\mathrm{S}, \mathrm{C}_{20} \mathrm{C}_{20}, \mathrm{C}_{20} \mathrm{C}_{25}$ and $\mathrm{C}_{40} \mathrm{C}_{40}$ standards.

phospholipid shown here in Methanospirillum hungatii were earlier misidentified as glycolipids. However, total polar lipid patterns are very similar for the two studies.

\section{Analysis of ether core lipids}

Analyses of halophilic archaebacteria have shown that those with similar polar lipids have identical isopranoid glycerol ether core lipids, either $\mathrm{C}_{20} \mathrm{C}_{20}$ diethers or a mixture of $\mathrm{C}_{20} \mathrm{C}_{20}$ and $\mathrm{C}_{20} \mathrm{C}_{25}$ diethers (Ross et al., 1985). The distribution of ether core lipids in methanogens analysed to date (Balch et al., 1979; Langworthy et al., 1982) is consistent with generic groupings derived by $16 \mathrm{~S}$ rRNA cataloguing. Using the acid methanolysis and chromatographic procedures of Ross et al. $(1981,1985)$ we have determined the types of ether core lipids possessed by all the strains listed in Table 1. A typical chromatogram is shown in Fig. 6 and the results are summarized in Table 2 . In general the results agree with those previously reported in that all the examples tested from the genera Methanobrevibacter, Methanobacterium and Methanospirillum possess a mixture of $\mathrm{C}_{20} \mathrm{C}_{20}$ and $\mathrm{C}_{40} \mathrm{C}_{40}$ core ethers (e.g. Fig. $6 d$ ) as resolved by these chromatographic procedures. Methanogenium spp. and Methanoplanus spp., which have not been analysed before, also possess a mixture of $\mathrm{C}_{20} \mathrm{C}_{20}$ and $\mathrm{C}_{40} \mathrm{C}_{40}$ core ethers. Methanococcus spp. (e.g. Fig. $6 c$ ) as previously indicated, have only $\mathrm{C}_{20} \mathrm{C}_{20}$ core ethers.

It has been reported that Methanosarcina spp. contain only $\mathrm{C}_{20} \mathrm{C}_{20}$ diethers (Balch et al., 1979 ; Langworthy et al., 1982). The pattern shown here (Fig. 6 b) for both Methanosarcina spp. is considerably more complex, indicating the likely presence of both $\mathrm{C}_{20} \mathrm{C}_{20}$ and $\mathrm{C}_{20} \mathrm{C}_{25}$ core ethers together with a slow moving component and a component of mobility intermediate between $\mathrm{C}_{20} \mathrm{C}_{20}$ and $\mathrm{C}_{40} \mathrm{C}_{40}$ ether core lipids. It is worth noting that Methanolobus tindarius has an identical core lipid pattern to Methanosarcina spp., a further indication of a possible close phylogenetic relationship.

Methanomicrobium mobile (Fig. $6 a$ ) exhibits an even more complex pattern of novel core lipids as well as $\mathrm{C}_{20} \mathrm{C}_{20}$ and $\mathrm{C}_{40} \mathrm{C}_{40}$ components. Methanothermus fervidus is equally interesting in uniquely lacking $\mathrm{C}_{20} \mathrm{C}_{20}$ core ethers (Fig. 6e), probably having a roughly equal mixture of a $\mathrm{C}_{40} \mathrm{C}_{40}$ core ether and a component similar in mobility to the slow moving component of 
Table 2. Core lipids of methanogens

\begin{tabular}{|c|c|c|c|c|}
\hline \multirow[b]{2}{*}{ Species } & \multicolumn{4}{|c|}{ Core ether lipids* } \\
\hline & $\mathrm{C}_{20} \mathrm{C}_{20}$ & $\mathrm{C}_{20} \mathrm{C}_{25}$ & $\mathrm{C}_{40} \mathrm{C}_{40}$ & $?$ \\
\hline Methanobacterium bryantii & + & - & + & - \\
\hline Methanobacterium formicicum & + & - & + & - \\
\hline Methanobacterium thermoautotrophicum & + & - & + & - \\
\hline Methanobrevibacter smithii & + & - & + & - \\
\hline Methanobrevibacter ruminantium & + & - & + & - \\
\hline Methanobrevibacter arboriphilicus & + & - & + & - \\
\hline Methanothermus fervidus & - & - & + & $+^{a}$ \\
\hline Methanococcus vannielii & + & - & - & - \\
\hline Methanococcus voltae & + & - & - & - \\
\hline Methanococcus thermolithotrophicus & + & - & - & - \\
\hline Methanomicrobium mobile & + & - & + & $+b$ \\
\hline Methanogenium cariaci & + & - & + & - \\
\hline Methanogenium marisnigri & + & - & + & - \\
\hline Methanogenium thermophilicum & + & - & + & - \\
\hline Methanospirillum hungatii & + & - & + & - \\
\hline Methanoplanus limicola & + & - & + & - \\
\hline Methanosarcina barkeri & + & + & $(+)$ & $t^{c}$ \\
\hline Methanosarcina mazei & + & + & $(+)$ & $+^{d}$ \\
\hline Methanolobus tindarius & + & + & $(+)$ & $+d$ \\
\hline
\end{tabular}

${ }^{*}(+)$, Trace amount; ${ }^{a}$, see Fig. $6(e) ;{ }^{b}$, see Fig. $6(a) ;{ }^{c}$, see Fig. $6(b) ;{ }^{d}$, as Fig. $6(b)$.

Methanosarcina spp. The characteristic nature of these novel core ether lipids may offer a further means to rapid identification for these genera, although other isolates have yet to be screened.

Definitive classification of a new isolate may in the end depend on nucleic acid analyses in view of the relative physiological uniformity of the group, but our results have shown that the procedures described here provide a useful and rapid indication of the likely taxonomic status of a new isolate.

\section{REFERENCES}

ARCher, D. B. \& Harris, J. E. (1985). Methanogenic bacteria and methane production in various habitats. In Anaerobic Bacteria in Habitats Other Than Man. Society for Applied Bacteriology Symposium 13. Edited by E. M. Barnes \& G. C. Mead. Oxford: Blackwell Scientific Publications (in the Press).

Balch, W. E., Fox, G. E., Magrum, L. J., Woese, C. R. \& Wolfe, R. S. (1979). Methanogens: reevaluation of a unique biological group. Microbiological Reviews 43, 260-296.

BLIGH, E. G. \& Dyer, W. J. (1959). A rapid method of total lipid extraction and purification. Canadian Journal of Biochemistry and Physiology 37, 911-917.

De Rosa, M., Gambacorta, A., Nicolaus, B., Ross, H. N. M., Grant, W. D. \& Bu'Lock, J. D. (1982). An asymmetric archaebacterial diether lipid from alkaliphilic halophiles. Journal of General Microbiology 128, 343-348.

Dittmer, J. C. \& Lester, E. L. (1964). A simple, specific spray for the detection of phospholipids on thin-layer chromatograms. Journal of Lipid Research 5, 126-127.

Fox, G. E., Luehrsen, K. E. \& Woese, C. R. (1982). Archaebacterial 5S ribosomal RNA. Zentralblat für Bakteriologie, Mikrobiologie und Hygiene (Abteilung I, Originale C) 3, 330-345.

JACIN, H. \& Mishkin, A. R. (1965). Separation of carbohydrates on borate impregnated silica gel plates. Journal of Chromatography 18, 170-176.

JoNes, W. J., Leigh, J. A., MAYER, F., Woese, C. R. \& WOLFE, R. S. (1983). Methanococcus jannaschii sp. nov. : an extremely thermophilic methanogen from a submarine hydrothermal vent. Archives of Microbiology 135, 91-97.

Kushwaha, S. C., Kates, M., Sprott, G. D. \& Smith, I. C. P. (1981). Novel polar lipids from the methanogen Methanospirillum hungatei GP1. Biochimica et biophysica acta 664, 156-173.

Langworthy, T. A., Tornabene, T. G. \& Holzer, G. (1982). Lipids of archaebacteria. Zentralblatt für Bakteriologie, Mikrobiologie und Hygiene (Abteilung 1, Originale C) 3, 228-244.

Macario, A. J. L. \& Conway de Macario, E. (1983). Antigenic fingerprinting of methanogenic bacteria with polyclonal antibody probes. Systematic and Applied Microbiology 4, 451-458.

Minnikin, D. E., Collins, M. D. \& Goodfellow, M. (1979). Fatty acid and polar lipid composition in the classification of Cellulomonas, Oerskotia and related taxa. Journal of Applied Bacteriology 47, 87-95.

Ross, H. N. M. \& Grant, W. D. (1985). Nucleic acid studies on halophilic archaebacteria. Journal of General Microbiology 131, 165-173.

Ross, H. N. M., Collins, M. D., Tindall, B. J. \& 
Grant, W. D. (1981). A rapid procedure for the detection of archaebacterial lipids in halophilic bacteria. Journal of General Microbiology 123, 75-80.

Ross, H. N. M., Grant, W. D. \& HaRris, J. E. (1985). Lipids in archaebacterial taxonomy. In Chemical Methods in Bacterial Systematics, pp. 289-299. Edited by M. Goodfellow \& D. E. Minnikin. London \& New York: Academic Press.

SCHERER, P. \& KNEIFEL, H. (1983). Distribution of polyamines in methanogenic bacteria. Journal of Bacteriology 154, 1315-1322.

Schmid, G. \& Bock, A. (1981). Immunological comparison of ribosomal proteins from archaebacteria. Journal of Bacteriology 147, 282-288.
Sowers, K. R., Johnson, J. L. \& Ferry, J. G. (1984). Phylogenetic relationships among the methylotrophic methane-producing bacteria and emendation of the family Methanosarcinaceae. International Journal of Systematic Bacteriology 34, 444-450.

Tu, J., Prangishvilli, D., Huber, H., Wildgruber, G., Zillig, W. \& SteTter, K. O. (1982). Taxonomic relations between archaebacteria, including six novel genera, examined by cross-hybridization of DNAs and 16S rRNAs. Journal of Molecular Evolution 18, 109-114. 